\title{
Detection of an Intermediate Filament Protein in the Pancreas and Mandibular Salivary Gland of the Goat (Capra hircus): An Immunocytochemical Study
}

\author{
Yaser Hosny Ali Elewa ${ }^{1,2^{*}}$, Shafika AM Elsayed ${ }^{1}$, Sherif Kh A Mohamed ${ }^{3}$ and Attia AA Moselhy ${ }^{3}$
}

${ }^{1}$ Department of Histology and Cytology, Faculty of Veterinary Medicine, Zagazig University, 44519, Egypt

${ }^{2}$ Laboratory of Anatomy, Basic Veterinary Sciences, Faculty of Veterinary Medicine, Hokkaido University, 060-0818, Japan

${ }^{3}$ Department of Anatomy and Embryology, Faculty of Veterinary Medicine, Zagazig University, Zagazig, 44511, Egypt

*Corresponding author: Yaser Hosny Ali Elewa, Laboratory of Anatomy, Basic Veterinary Sciences, Faculty of Veterinary Medicine, Hokkaido University, 060-0818, Japan, Tel: 011-706-5188; Fax: 011-706-5189; E-mail: y-elewa@vetmed.hokkudai.ac.jp

Rec date: November 22, 2017; Acc date: November 29, 2017; Pub date: November 30, 2017

Copyright: ( 2017 Elewa YHA, et al. This is an open-access article distributed under the terms of the Creative Commons Attribution License, which permits unrestricted use, distribution, and reproduction in any medium, provided the original author and source are credited.

\begin{abstract}
The centroacinar cells (CACs) are a specialized ductal pancreatic cell. Recently, it has been revealed that such cells showed a progenitor function in the pancreas of adult mouse and zebrafish. However, no information about its occurrence in other exocrine glands specially in farm animals. Cytokeratins immunohistochemistry was used to detect ductal segments of the submandibular glands and the pancreas including CACs in human and rat. In the present study, the detection of cytokeratins in the normal goat pancreas (a serous type gland) and mandibular salivary gland (a mixed type gland, consisted of mucous tubules capped with serous demilunes) was investigated using a standard immunoperoxidase technique on paraffin sections. In the goat pancreas and mandibular salivary gland, cytokeratins were found in all duct cells including the CACs of the pancreas. Interestingly in the mandibular salivary glands, some immunoreacted cells with immunopositive cytoplasmic extensions were frequently observed between the cytoplasm of the mucous cells, especially near the lumina of the mucous tubules. We postulate that these cells could be centroacinar- like cells. Therefore, from these findings, it can be concluded that these cells could provide a supportive cytoskeleton to maintain cellular shape and avoid the collapse of the mucous cells during mucous secretion. Additionally, a regenerative function for such cells could be hypothesized. Furthermore, the keratin demonstration could be used as a marker for ductal cells and is a useful aid in the detection of lesions derived from gland ductal cells in goat. Further research is necessary to investigate the expression of keratins in caprine glandular tumors as well as the regenerative ability of these centroacinar- like cells in goat mandibular salivary glands injury.
\end{abstract}

Keywords: Cytokeratins; Pancreas; Mandibular salivary glands; Goat

\section{Abbreviations}

CK: Cytokeratins; CACs: Centroacinar cells.

\section{Introduction}

Intermediate filaments include five classes: a) keratin in epithelial cells; b) vimentin in mesenchymal cells; c) desmin predominantly in muscle cells; d) neurofilaments, in neurons; e) glial in glial cells [1]. Cytokeratins (CK) constitute the cytoskeleton of epithelial mammalian cells [2]. At least 20 different CKs have been described, which exhibit a highly diverse expression in various epithelia $[3,4]$. These cytokeratins have been characterized and classified on the basis of molecular weight into two types; Type-I (A) CKs are small, acidic and encoded by genes located on chromosome 17, which include CK9-CK20, whereas type-II (B) CKs are large, basic, and encoded by genes on chromosome 12 and include CK1-CK8 [2].

Previously, we have studied the distribution of vimentin in the goat salivary glands immunohistochemically [5]. Distribution of cytokeratins has been studied in humans and in laboratory animals. They have been detected in ductal segments of the submandibular glands in human [6] and rat [7]. Furthermore, cells from the excretory ducts of the rat pancreas including the centroacinar cells (CACs) showed immunopositive reaction for different cytokeratins antibodies $[8,9]$. However, little has been elucidated so far concerning their distribution in farm animals, especially in goats [10].

Despite the important role of the cytokeratins as a cytoskeleton of glandular cells, the available literature concerning the ruminant salivary glands lacked data about their distribution and was concerned mainly with the localization of both sialoglycoconjugates and antimicrobial substances [11].

The salivary glands and exocrine pancreas have many histological and functional correlations. The salivary gland function is frequently impaired with chronic pancreatitis of various etiologies, including autoimmune and idiopathic chronic pancreatitis. An immune response directed against the pancreatic ductal system also adversely affects the salivary ducts [12]. Therefore, the aim of the present paper was to describe the distribution of cytokeratins as intermediate filaments in both goat pancreas and mandibular salivary glands, and to discuss the findings with respect to the physical properties of secretions of these different glands. Furthermore, improved knowledge of the keratin distribution in goat pancreas and salivary glands is important not only from a biological point of view but also because of their important role in the diagnosis of some gland lesions and tumors $[13,14]$. 
Citation: Elewa YHA, Elsayed SAM, Mohamed SKA, Moselhy AAA (2017) Detection of an Intermediate Filament Protein in the Pancreas and Mandibular Salivary Gland of the Goat (Capra hircus): An Immunocytochemical Study. J Vet Sci Technol 8: 496. doi: $10.4172 / 2157-7579.1000496$

Page 2 of 5

\section{Materials and Methods}

\section{Animals}

The central part of the pancreas and mandibular salivary glands of ten healthy goats of both sexes, aged from 12 to 24 months, were collected immediately after slaughter from the Zagazig abattoir, Egypt. This experiment was carried out according to the institutional ethical committee of the Zagazig University, Egypt.

\section{Light microscopy}

Freshly collected specimens from the pancreas and mandibular salivary glands were fixed immediately in $10 \%$ neutral buffered formalin for $24 \mathrm{~h}$. They were then dehydrated in ascending grades of ethanol, cleared in xylene and embedded in paraffin wax using routine histological techniques. $3 \mu \mathrm{m}$ thick histological sections were stained with hematoxylin-eosin (H\&E) for cellular morphological analysis. The employed methods of processing and staining were adopted from [15].

\section{Immunohistochemistry}

Immunohistochemical techniques were used to examine the distribution of the cytokeratins, on the paraffin sections (streptavidinbiotin technique) using monoclonal mouse anti-human cytokeratin ( $\mathrm{M}$ 3515, Dako, Carpinteria, CA, USA), which was reported to be immunoreactive with antigenic determinants present in all cytokeratins except numbers 12,17 and 18 .

Deparaffinized sections, $3 \mu \mathrm{m}$ thick, were rehydrated in a descending graded alcohol series and washed twice with distilled water for $5 \mathrm{~min}$ each time. Antigen retrieval was conducted for all sections using heat-induced epitope retrieval, through immersion of tissue sections in citrate buffer, $\mathrm{pH} 6.0$, autoclaved at $105^{\circ} \mathrm{C}$, for $20 \mathrm{~min}$. Endogenous peroxidase was blocked by incubating sections in $3 \%$ $\mathrm{H}_{2} \mathrm{O}_{2}$ in absolute methanol for $30 \mathrm{~min}$ at $4^{\circ} \mathrm{C}$, followed by flushing with water and incubation with $10 \%$ normal rabbit serum for $1 \mathrm{~h}$ at room temperature. The sections were incubated overnight with the specific primary antibody (monoclonal mouse anti-human cytokeratin) diluted at $1: 150$ in $1.5 \%$ bovine serum albumin (BSA)/ phosphate buffer saline (PBS), $\mathrm{pH}$ 7.2. For negative control sections, PBS was used instead of the primary antibody. Sections were washed three times in PBS (5 min each), followed by incubation with biotinconjugated rabbit anti-mouse IgG antiserum (Histofine kit, Nichirei Corporation) for $60 \mathrm{~min}$. Sections were then washed three times in PBS (5 min each), followed by incubation with streptavidin-peroxidase conjugate (Histofine kit, Nichirei Corporation) for $30 \mathrm{~min}$. The streptavidin-biotin complex was visualized with 3, 3'diaminobenzidine tetrahydrochloride (DAB) $-\mathrm{H}_{2} \mathrm{O}_{2}$ solution, $\mathrm{pH}$ 7.0, for $3 \mathrm{~min}$. Sections were washed in distilled water, and finally counterstained slightly with Harris hematoxylin.

\section{Results}

\section{Histology of the pancreas}

The goat pancreas was composed of exocrine and endocrine components. The latter formed the islets of Langerhans and were scattered among the exocrine components. The exocrine components consisted of compound tubuloacinar glands of a pure serous type that conveyed their secretion through ducts. The secretory units were acinar or tubuloacinar in shape with narrow lumina that were formed by pyramidal serous cells. As unique to the pancreas in mammals, the intercalated ducts that lead from the secretory endpeices began within the latter as centroacinar cells (Figure 1a).

\section{Immunohistochemical observations of the pancreas}

Immunohistochemical staining of the pancreas for cytokeratins revealed that the cytoplasm of all ductal cells including the centroacinar cells were immunopositive. However, those of the acinar and Langerhans cells were immunonegative (Figure 1b-1d).

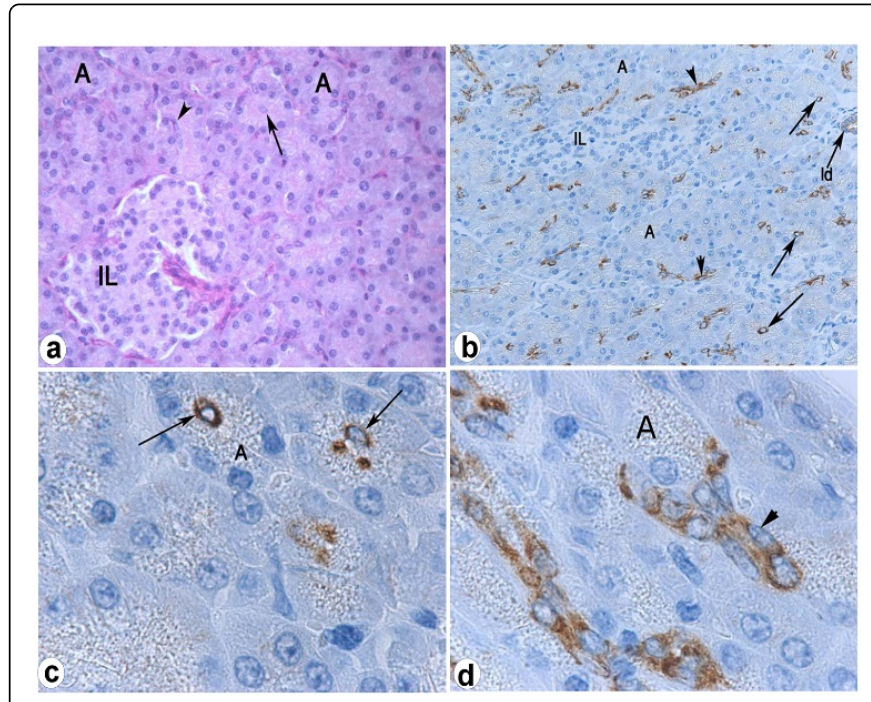

Figure 1: Photomicrographs of goat pancreas: (a) $\mathrm{H}$ and $\mathrm{E}$ - stained section (b-d) Immunohistochemical staining with the anticytokeratin antibody. Notice serous acini (A), islet of langerhans (IL), centroacinar cells (arrows), intercalated duct cell (arrow heads) and interlobular duct (Id). (a: 400x; b: 200x; c and d: 1000x).

\section{Histological observations of the mandibular salivary glands}

The mandibular salivary gland in goat is a compound tubuloalveolar mixed type. The parenchyma was formed from secretory endpieces and ductal system. The former consisted mainly of mucous tubules capped with serous demilunar cells with the presence of few serous acini. The ductal system included the intercalated, striated, interlobular and excretory ducts (Figure 2a). The intercalated ducts were not seen very frequently in sections and were lined with simple squamous to low cuboidal epithelium. Sporadic cells were occasionally observed between the mucous cells of the seromucous tubules. Some of these cells were observed near the lumen (Figure $2 \mathrm{a}$ and $2 \mathrm{~b}$ ). 
Citation: Elewa YHA, Elsayed SAM, Mohamed SKA, Moselhy AAA (2017) Detection of an Intermediate Filament Protein in the Pancreas and Mandibular Salivary Gland of the Goat (Capra hircus): An Immunocytochemical Study. J Vet Sci Technol 8: 496. doi: $10.4172 / 2157-7579.1000496$

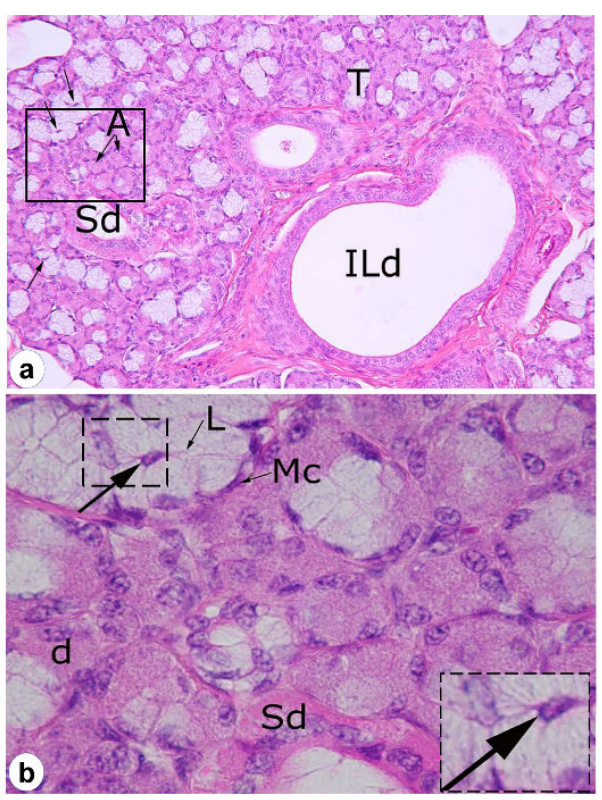

Figure 2: Photomicrographs of goat mandibular salivary gland: (a) $\mathrm{H}$ and $\mathrm{E}$ - stained section showing serous acini (A), seromucous tubule $(\mathrm{T})$, sporadic cells between the mucous cells (arrows), striated duct (Sd) and interlobular duct (Id). (b) Higher magnification of the boxed area in (a) showing striated duct (Sd), mucous cell $(\mathrm{Mc})$, serous demilunar cell (d), lumen of seromucous tubule (L) and sporadic cells extend near the lumen (arrow). The inset showed higher magnification of the dashed square in figure $\mathbf{b}$ (a: 200x; b: 400x; inset: 1000x).

\section{Immunohistochemical observations of the mandibular salivary glands}

Immunopositive staining for cytokeratin in the mandibular salivary gland was found in the cytoplasm of all ductal cells (Figure 3a). Furthermore, the cytoplasm of the sporadic cells that were frequently observed among the mucous cells, were also immunopositive (Figure 3a-3d). However, the cytoplasm of both myoepithelial and secretory endpiece cells were immunonegative (Figure 3c). Additionally, some of these immunopositive cells showed immunopositive cytoplasmic processes extending between the cytoplasm of the mucous cells towards the lumina of the mucous tubules (Figure $3 \mathrm{~d}$ ).

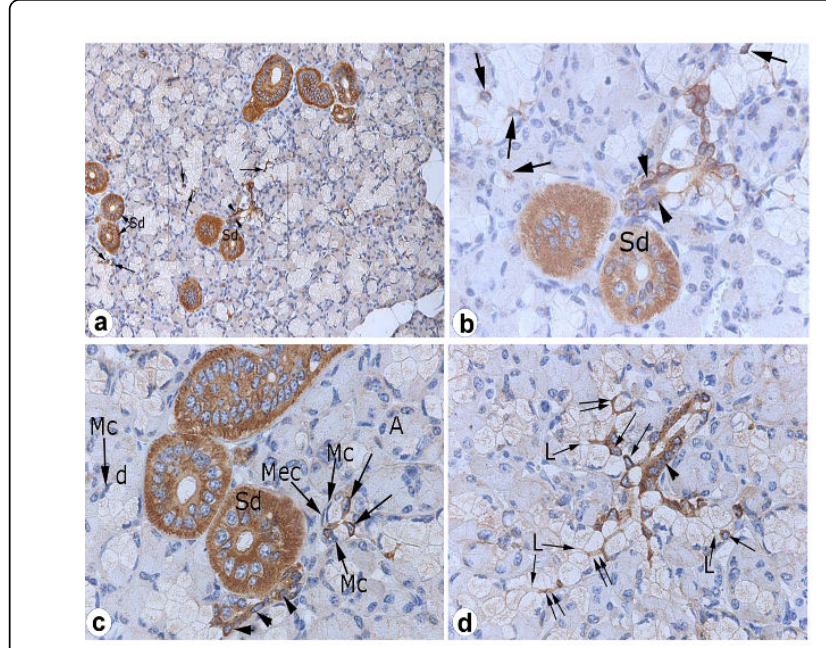

Figure 3: Photomicrographs of immunohistochemical stained goat mandibular salivary gland sections with anticytokeratin antibody: (a-d) showing immunopositive staining in all ductal cells including striated duct (Sd), intercalated duct (arrow heads) and sporadic cells between the mucous cells (arrows). Notice immunposositive cytoplasmic extensions (double arrows), negative reaction of the myoepithelial cells $(\mathrm{Mec})$, mucous cells $(\mathrm{Mc})$, serous demilunar cell (d), and serous acini (A). (a: 200x; b, c and d: 400x).

\section{Discussion}

In ruminants, the salivary glands produce copious amounts of saliva, as much as 6 to $16 \mathrm{~L}$ per day in sheep and goats and 100-190 L in cattle [16]. Both the saliva and the pancreatic secretion have important digestive functions where it contains enzymes such as amylase and lipase that facilitate the breakdown of ingested food [17].

The present study revealed that the pancreas was of serous type, similar to that of the other mammalian species [18], whereas the mandibular salivary gland was of mixed type, similar to previous studies [19,20]. Additionally, in H\&E stained sections of the mandibular salivary glands of the present study, sporadic cells were occasionally observed between the mucous cells of the seromucous tubules. Some of these cells were observed to extend near the lumen.

Previous studies have demonstrated the histochemistry of polysaccharides, contents of various sialic acids and the distribution of these anti-microbial substances in the goat mandibular salivary gland $[11,21,22]$. However, data are lacking concerning the distribution pattern of cytokeratins in different glands in goat, despite their major role as a cytoskeleton of epithelial mammalian cells.

In the present investigation, immunohistochemical detection of cytokeratins distribution was performed through incubation with monoclonal mouse anti-human cytokeratin (Clones AE1/AE3). Such antibody was formed from a cocktail of two monoclonal antibodies [23]. AE1 immunoreacts with an antigenic determinant present on most of the subfamily A cytokeratins, including cytokeratins 10, 13, 14, 1516 and 19 but not on Nos. 12, 17 and 18 [24]. Antibody AE3 reacts with an antigenic determinant shared by the subfamily B cytokeratins CK1-CK8 [25]. In different types of epithelia, keratin filaments are composed of one type-I and one type-II CK where different keratin 
Citation: Elewa YHA, Elsayed SAM, Mohamed SKA, Moselhy AAA (2017) Detection of an Intermediate Filament Protein in the Pancreas and Mandibular Salivary Gland of the Goat (Capra hircus): An Immunocytochemical Study. J Vet Sci Technol 8: 496. doi: $10.4172 / 2157-7579.1000496$

Page 4 of 5

isoforms are differentially expressed during development and differentiation $[26,27]$.

In accordance with previous immunohistochemical studies of keratin distribution in salivary glands of mammals [7,10], the present study revealed that, the cytoplasm of all ductal cells in both the mandibular salivary gland and the pancreas including centroacinar cells were strongly immunopositive to the cytokeratin. However, the cells forming secretory endpeices were negatively reacted. The positive reaction of all ductal cells emphasized the major role of cytokeratin as a cytoskeletal protein to maintain the cellular shape of the ducts, while, the negative reaction observed in the cells forming secretory endpeices suggest the role of these cells in the secretion of either saliva or pancreatic secretion with no keratin synthesis process.

Interestingly, the sporadic cells that were observed in H\&E stained sections among the mucous cells of the seromucous tubules in the mandibular salivary gland of goat, showed strong immunopositive reaction similar to that observed in other ductal cells. We suggested that these cells could be extensions of the intercalated ducts into the secretory endpeices similar to that occurring in the pancreas, but not in a central position of the secretory endpieces. Therefore, we postulate that these cells could be centroacinar- like cells. This result was consistent with a previous study in the submandibular salivary gland of the European hedgehog [28]. The latter reported that the intercalated ducts penetrated a short distance into the secretory acini, in much the same manner as in CACs of the exocrine pancreas but in an offset position and describe these cells as lateroacinar cells. A similar duct / acinus relationship has been also reported in the lateral nasal (steno's) gland of the rat [29]. Additionally, we demonstrated that immunopositive cytoplasmic processes were frequently extended from some of these immunopositive cells in between the cytoplasm of the mucous cells toward the lumina of the mucous tubules. Regarding the role of both immunopositive cells and their cytoplasmic extension, we suggest their role as a cytoskeleton protein to maintain the cellular shapes and probably to prevent the collapse of attenuated cytoplasm of mucous cells.

Recently, there are several approaches for treatment salivary gland dysfunction using salivary gland germ regeneration methods [30]. However, little is known about the presence of some salivary gland cells that could show a progenitor function. Interestingly, it has been reported that the CACs of the pancreas in adult mouse and zebrafish showed a progenitor function and may contribute to the maintenance of tissue homeostasis [31,32]. Similarly, we revealed the presence of centroacinar-like cells in the goat submandibular salivary glands and we hypothesize that cells could have a regenerative role. However, further investigations are required to prove such role in injured goat submandibular salivary glands.

In conclusion, the immunohistochemical distribution of cytokeratin proteins in different goat glands showed diverse reactions among their compartments. In both mandibular salivary glands and pancreas, all cells forming the ducts were immunopositive, while that forming the secretory endpeices were negatively reacted. This reflects the major role of cytokeratin as a cytoskeletal protein to all ductal cells. Additionally, in the mandibular salivary glands, the presence of immunopositive cells and cytoplasmic extensions among the mucous cells postulate their key role in supporting these cells to prevent their collapse during their secretory activity and suggest that the keratin demonstration could be used as a marker for ductal cells and is a useful aid in the detection of lesions derived from gland ductal cells in goat. Further morphological and functional investigations were needed to clarify the role of such cells in goat mandibular salivary glands, as well as the expression of keratins in caprine glandular tumors.

\section{References}

1. Lazarides E (1980) Intermediate filaments as mechanical integrators of cellular space. Nature 283: 249-255.

2. Chu PG, Weiss LM (2002) Keratin expression in human tissues and neoplasms. Histopathology 40: 403-439.

3. Moll R, Franke WW, Schiller DL, Geiger B, Krepler R (1982) The catalog of human cytokeratins: patterns of expression in normal epithelia, tumors and cultured cells. Cell 31: 11-24.

4. Moll R (1998) Cytokeratins as markers of differentiation in the diagnosis of epithelial tumors. Subcell Biochem 31: 205-262.

5. Elewa YH, Bareedy MH, Abuel-Atta AA, Ichii O, Otsuka S, et al. (2010) Structural characteristics of goat (Capra hircus) parotid salivary glands. Jpn J Vet Res 58: 121-135.

6. Mori M, Noriyasu M, Kyung HH, Shinichiro S, Kenichi K (1985) Immunohistochemical studies of keratin distribution in salivary gland tumors. Acta Histochemica et Cytochemica 18: 21-32.

7. Dozic I, Tatjana T, Dozic B, Colic M (2009) Immunohistochemical identification of cytokeratins in the rat submandibular salivary glands during ontogenesis. Acta Veterinaria 59: 69-80.

8. Bouwens L, Braet F, Heimberg H (1995) Identification of rat pancreatic duct cells by their expression of cytokeratins 7, 19, and 20 in vivo and after isolation and culture. J Histochem Cytochem 43: 245-253.

9. Bouwens L (1998) Cytokeratins and cell differentiation in the pancreas. J Pathol 184: 234-239.

10. Takai Y, Nodo Y, Sumitomo S, Kawamura K, Mori M (1985) Immunohistochemical detection of keratin proteins in salivary glands ducts of mammals. Acta Histochemica et Cytochemica 18: 353-361.

11. Habata I, Yasui T, Fujimori O, Tsukise A (2012) Immunohistochemical aspects of anti-microbial properties in goat submandibular glands. Anat Histol Embryol 41: 54-59.

12. Kamisawa T, Tu Y, Egawa N, Sakaki N, Inokuma S, et al. (2003) Salivary gland involvement in chronic pancreatitis of various etiologies. Am J Gastroenterol 98: 323-326.

13. Ferrer L, Rabanal RM, Fondevila D, Prats N (1990) Immunocytochemical demonstration of intermediate filament proteins, S-100 protein and CEA in apocrine sweat glands and apocrine gland derived lesions of the dog. Zentralbl Veterinarmed A 37: 569-576.

14. Nikitakis NG, Tosios KI, Papanikolaou VS, Rivera H, Papanicolaou SI, et al. (2004) Immunohistochemical expression of cytokeratins 7 and 20 in malignant salivary gland tumours. Mod Pathol 17: 407-415.

15. Bancroft GD, Gamble M (2007) Theory and practice of histopathological technique. 6th edn. London, Melbourne and New York.

16. Blair-West JR, Coghlan JP, Denton DA, Wright RD (1967) Effect of endocrines on salivary glands. In: Code CF (ed). Handbook of Physiology, Alimentary Canal. Williams and Wilkins, pp: 633-664.

17. Kamisawa T, Tu Y, Sasaki R, Egawa N, Kamata N, et al. (2007) The relationship of salivary gland function to elevated serum IgG4 in autoimmune pancreatitis. Intern Med 46: 435-439.

18. Samuelson DA (2007) Digestive system II: Glands, Chapter 15. In: Textbook of veterinary histology. Philadelphia, USA: Saunders Elsevier, pp: 353-370.

19. Suzuki S, Otsuka J (1976) On the fine structure of salivary glands of goat and dog: II. Mandibular gland. Bull Fac Agr Kagoshima Univ 26: 43-57.

20. Rauf SM, Islam MR, Anam MK (2004) Macroscopic and microscopic study of the mandibular salivary gland of Black Bengal goats. Bangl J Vet Med 2: 137-142.

21. El-Shafey SM, Al-Shaikhly AK, Al-Lawand S (1980) Micromorphology and histochemistry of polysaccharides in the goat mandibular salivary gland. Anat Anz 147: 33-41. 
Citation: Elewa YHA, Elsayed SAM, Mohamed SKA, Moselhy AAA (2017) Detection of an Intermediate Filament Protein in the Pancreas and Mandibular Salivary Gland of the Goat (Capra hircus): An Immunocytochemical Study. J Vet Sci Technol 8: 496. doi: $10.4172 / 2157-7579.1000496$

Page 5 of 5

22. Habata I, Yasui T, Tsukise A (2011) Histochemistry of sialoglycoconjugates in goat submandibular glands. Anat Histol Embryol 40: 187-195.

23. Woodcock-Mitchell J, Eichner R, Nelson WG, Sun TT (1982) Immunolocalization of keratin polypeptides in human epidermis using monoclonal antibodies. J Cell Biol 95: 580-588.

24. Sun TT, Eichner R, Schermer A, Cooper D, Nelson WG, et al. (1984) Classification, expression and possible mechanisms of evolution of mammalian epithelial keratins: A unifying model. In: Levine A, Topp W, Vande Woude G, Watson JD (eds.) The cancer cells, vol 1. The transformed phenotype, New York: Cold Spring Harbor Laboratory, pp: 169-176.

25. Eichner R, Bonitz P, Sun TT (1984) Classification of epidermal keratins according to their immunoreactivity, isoelectric point and mode of expression. J Cell Biol 98: 1388-1396.

26. Van de Rijn M, Perou CM, Tibshirani R, Haas P, Kallioniemi O, et al. (2002) Expression of cytokeratins 17 and 5 identifies a group of breast carcinomas with poor clinical outcome. Am J Pathol 161: 1991-1996.
27. Vlasoff DM, Baschinsky DY, Frankel WL (2002) Cytokeratin 5/6 immunostaining in hepatobiliary and pancreatic neoplasm. Appl Immunohistochem Mol Morphol 10: 147-151.

28. Tandler B, MacCallum DK (1974) Ultrastructure and histochemistry of submandibular gland of the European hedgehog, Erinaceus europaeus L. II. Intercalated ducts and granular striated ducts. J Anat 117: 117-131.

29. Moe H, Bojsen-Moller F (1971) The fine structure of lateral nasal gland (steno's gland) of the rat. J Ultrastruct Res 36: 127-148.

30. Ogawa M, Tsuji T (2017) Functional Salivary Gland Regeneration. Methods Mol Biol 1597: 135-151.

31. Roviraa M, Scotta SG, Lissb AS, Jensenc J, Thayerb SP, et al. (2010) Isolation and characterization of centroacinar/terminal ductal progenitor cells in adult mouse pancreas. Proc Natl Acad Sci USA 107: 75-80.

32. Beer RL, Parsons MJ, Rovira M (2016) Centroacinar cells: At the center of pancreas regeneration. Dev Biol 413: 8-15. 